\title{
$\infty$ \\ CAN THE REAL CITIZEN STAND UP PLEASE? \\ THE ELUSIVENESS OF THE CITIZEN \\ IN THE MIDDLE EAST
}

\author{
e \\ "They seek him here, they seek him there, those Frenchies seek him everywhere; \\ Is he in heaven, is he in hell, that damned illusive Pimpernel?» \\ The Scarlet Pimpernel
}

ROEL MEIJER

This article deals with the debate about citizenship. It discusses Nils A. Butenschøn's «citizenship approach» and tries to historicize his theory and project it back to the nineteenth century and the interbellum, in an attempt to draw an outline of the history of citizenship in the Middle East. Citizenship is an elusive subject and this essay seeks to demonstrate the usefulness of applying the term citizenship to the Middle East. The main reason for raising this question is that scholars of the Middle East seldom use the term, or if they do, they do so in a random off-hand way, assuming that citizenship is an unproblematic concept, such as in the "citizens of the Ottoman Empire», the «citizens» of Egypt, or even the "citizens of Qatar» in an exhibition at Qatar museum on Qatari workers who supposedly built their country in the early oil industry in the 1950s. Seldom is the problematic character of the term citizenship recognized. Rarely is citizenship itself a topic of research, and if it is, this is mostly limited to one aspect of citizenship: nationality (in Arabic jinsiyya), in the sense of possessing a passport and being a subject of a state, or in the case of populations who do not have a fixed internationally recognized nationality, such as Palestinians and Kurds and the problematic character of their nationality. Even scholars who have given citizenship more thought disagree on its character. Will Hanley, who recently published a book on nationality in Alexandria at the end of the nineteenth century, has a highly legalistic view of citizenship, and argues that looking for substantial citizenship in the nineteenth century is compared to an «impossible quest for a Holy Grail of indigenous political citizenship that was destroyed by outside forces». He states that «there was no democratic citizenship» and therefore no subject to study at the end of nineteenth century because there were no rights, only duties. ${ }^{1}$ Elsewhere he refers to citizenship in Alexandria as the effect of «legal technologies». ${ }^{2}$ Others, like 
Bryan Turner, one of the founders of citizenship studies in the 1980s, has given more sociological reasons for its absence in the Middle East, pointing out that the tenacity of kinship relations prevented the emergence of individualism, a precondition of citizenship. ${ }^{3} \mathrm{He}$ finds company in Middle East specialist Sami Zubaida, who argues that the social relations in the region are based on kinship, clan and tribal relations and that the individual and the notion of rights is not sufficiently developed. ${ }^{4}$ On the other extreme, stands Engin Isin, who holds the opinion that these definitions of citizenship are too Western and Orientalist. He argues that citizenship should be based on a completely different set of criteria. According to his definition, citizenship already existed during the premodern Ottoman period. «Ottoman citizenship» was embodied in the way people organized, assembled, and differentiated themselves. These institutions, even more than Western reforms of the nineteenth century, have produced civil consciousness, civility, social responsibility and forms of identity, solidarity and loyalty that we associate with citizenship. ${ }^{5}$ In fact, the process of centralization, standardization, homogenization that is part of the Tanzimat reforms only produced an authoritarian state that ended local, deeply held notions and practices of citizenship. Among regional scholars, a comparable argument is found in Wael Hallaq's The Impossible State, in which he argues that modern surveillance states exclude sharia that buttressed an Islamic civil society sustained by the ulamä. ${ }^{6}$ In the same vein, Timothy Mitchell in his Colonizing Egypt argues that modern citizenship leads to a disciplinary regime of state surveillance. ${ }^{?}$

During the past decade much work has been done on notions of citizenship and the application of citizenship theory to the Middle East, and by now citizenship has become something of a discipline that helps us understand the Middle East in a new way. To these new trends belong the works of Gianluca Parolin, ${ }^{8}$ Lauren Banco, ${ }^{9}$ Michelle Campos, ${ }^{10}$ Elizabeth Thompson ${ }^{11}$ and Rania Maktabi. ${ }^{12}$ Their main success has been to retrieve citizenship as a subject from being crushed between the anvil of the «soft» approach that has attracted most scholarly attention such as Arab nationalism and its heavy emphasis on identity, and the anvil of «hard», realist, political science theories of authoritarian state resilience theories. There are also many studies that have indirectly contributed to the understanding of citizenship. To these belong, for example, recent works on sectarianism, ${ }^{13}$ the Ottoman empire, ${ }^{14}$ Muslim-Christian relations, ${ }^{15}$ studies on guilds, ${ }^{16}$ and all studies on workers and trade unions in the twentieth century Egypt. ${ }^{17}$ Reading these works through the lens of citizenship, one is struck by the proverbial elephant in the room. This is not surprising as the larger project of which citizens played a part was to build a new civic and political order in which citizenship was the central feature, even if it is not named as such. The end result is a new reading of Middle Eastern history.

Nils A. Butenschøn's Citizenship and the State in the Middle East: Approaches and Applications published in 2000, ${ }^{18}$ together with its companion, edited by Suad Joseph on gender and citizenship, ${ }^{19}$ belong to the first publications on the Middle East focusing on the concept of citizenship. Butenschøn's introduction to his anthology is the first attempt to theorize what he calls the «citizenship approach», and in many ways it is still valid. He argues that citizenship is the "organizing principle of state-society relations in modern states. It draws lines between members and nonmembers, between those who are included and those excluded from specific rights and obligations regulated by the authorities». ${ }^{20}$ Essentially this is a function of the state through its "politics of citizenship». The state provides for the right of abode (jinsiyya), or 
nationality as well as the right of «equal access to the civil, political, social, and economic resources of the state», ${ }^{21}$ or muwätana, in the case of democratic citizenship. Importantly, Butenschøn calls the relationship between state and citizen a social contract. This allows him to come to his main point that the crisis of the Middle East can be traced to «the lack of trust of the citizen in the state». In the second half of his introduction he defines different models of citizenship - what we have called "citizenship regimes" in the first anthology Nils A. Butenschøn and I edited in $2017^{22}$ - dividing the Middle East into singular and pluralistic regimes, with the first including Saudi Arabia, Turkey, and the second Lebanon. A third category, universalism, does not occur in the

Investigating citizenship in the region is investigating the deeper reasons for the

\section{present crisis.}

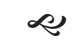

Middle East, but seems to be a future ideal, except perhaps Tunisia after 2011. Butenschøn's analysis focuses mainly on the period after independence and the crisis of legitimacy of the authoritarian regimes in the 1980 s. He takes into account the different forms of citizenship due to local circumstances and social formations, but his is essentially an ahistorical analysis. It focuses mainly on the authoritarian state and not on the agency of the people (demos), or social movements. Nor does he look at ideas and their role in the historical formation of citizenship in contestation with the state. What he does do, however, is provide the building blocks of the analysis of citizenship (the role of the state, state-citizen relations, social contract between state and citizen and legitimacy, collective or individual citizenship, tension between jinsiyya and muwātana).
These building blocks are essential in tracing the development of the citizen in the Middle East. They raise questions about the period when the modern state arose, which form it adopted, and which power mechanisms it developed and to what extent it became sovereign and gained full control over its subjects, turning them into citizens through legal procedures. It addresses the issue of inclusion and exclusion. The same applies to citizenship. When did a modern citizen arise and when did the transition take place from subject to citizen? This is not just the result of the rise of the modern state and its control mechanisms of individuals, because for a notion of citizenship to take hold, citizens must not only become aware of their duties to the state, but also of their rights, developing allegiances to larger political communities, and develop a sense of the common good. In Benedict Anderson's words, citizenship is an «imagined community», but it is also concrete in the sense that it relates to how it is expressed, organizes itself and produces certain practices. As such, citizenship is not just imposed by the state but is also constituted through participation and mobilization of social movements. More than in Europe, in the Middle East this has been a messy business, with partial successes, and more downs than ups. Citizenship has been diverse, highly differentiated, sometimes even disappearing, producing the so-called «child-citizen» under Hazfez al-Asad, ${ }^{23}$ or the noncitizen under Saddam Hussein. ${ }^{24}$ Another difference with Western Europe is the tremendous influence of foreign interference in development of citizenship in the Middle East. Foreign intervention and incorporation into the periphery of the world economic system has severely hampered sovereignty of the state and its capacity to acquire control over its population and implement a program of «citizenization». Because of privileges, trade arrangements and extraterritorial 
rights granted to specific groups, individuals, and religious minorities allied with European powers, many potential citizens redirected their loyalty to foreign powers, and had a complex, ambiguous relation with their own emerging state. Despite these caveats, it would be unwise not to look at these developments and only associate citizenship with complete sovereignty and the formation of the social contract of post-independence between state and people as this would neglect the previous Ottoman and colonial social contracts, or citizenship regimes. In fact, the authoritarian regimes and their so-called «ruling bargain» or «populistnationalist bargain» with the population cannot be understood properly without considering the previous citizenship regimes to which they were a reaction. One of the major advantages of the citizenship approach is to trace the development of concepts and practices of citizenship over a long period of time and study the transitions in citizenship regimes. As Nils A. Butenschøn and I argue in our two anthologies, investigating citizenship in the region is investigating the deeper reasons for the present crisis. ${ }^{25}$

In the remainder of this article I will look at three developments that shed light on citizenship before independence of Arab states in the 1950 .

\section{TANZIMAT AND THE MODERN OTTOMAN STATE}

One of the main issues of the nineteenth century is the rise of the modern state and its impact on the population and the transformation of subjects into citizens based on a new social contract. According to the classical Ottoman social contract the sultan provided protection of the Dar Islam, upheld the sharia, implemented justice and maintained the peace to ensure the prosperity of his subjects. In practice the power of the state remained limited; it was strongly decentralized, and only maintained indirect relations with the populations through intermediaries of local notables, guild and tribal sheikhs, and the military, who collected taxes for the state and kept part of the revenue for themselves. A separate contract was made with non-Muslims, which went back to the so-called contract of the second rightly guided caliph Umar. According to the pact, non-Muslims were protected in exchange for loyalty to the sultan and the payment of an extra tax, the jizya. ${ }^{26}$ In terms of citizenship, Muslims were privileged, non-Muslims were secondary citizens. But as Baki Tezcan argues both Muslims and non-Muslims belonged to the «flock» (reaya), and were treated the same and had to pay taxes. The real difference was between on the one hand the elite (khaa), the sultan, his servants (who were regarded as his slaves and could be dispossessed), the ulamä, and on the other hand, the masses ('amma). ${ }^{27}$

The Tanzimat (1839-1876) changed this traditional order. The main difference is that the state was completely reorganized, acquired unprecedented power and started to directly interfere in the lives of the population, not only through increased taxation but also through more detailed regulations and other control mechanisms. The increase in power is also exemplified in the introduction of conscription and a standing army in the 1830 s, which replaced the Janissaries who were slaughtered by Mahmud II in 1826 . By 1881 the army had increased to 300.000 troops. ${ }^{28}$ No less dramatic for the spread of the notion of modern citizenship was the attempt to introduce equality between Muslims, Jews and Christians in the two edicts, those of 1839 and 1856. The intention was to gain the loyalty of Christians and Jews - still 40 percent of the population - to the Ottoman state on the basis of a new social contract, called Ottomanism (Osmanlilik). ${ }^{29}$ In theory, this contract created equal citizenship. The earlier abolition of clothing laws and termination of the sartorial differences be- 
tween adherents of different religions was also an important measure that enhanced equality. ${ }^{30}$

The Ottoman attempt to create equal citizenship was, however, not an undivided success. Much depended on the capacity of the centralized empirical state to acquire sovereignty, but throughout the nineteenth century its power over its own territory and population was undermined. First through military defeats, ending in the Balkan wars of 1912-1913, when the Ottoman state lost almost all of its territory in Europe. Second, through the expansion of the Capitulations, foreign powers acquired greater influence over crucial sections of the population by giving them the status of foreign protégés. As a result, the richer members of the empire fell under foreign law and were exempt from paying taxes. While at first the status of protégés were limited to the dragomans, protégé status was extended to family members, other merchants, and later whole Christian communities. This was a universal development in the Middle East and North Africa. At a certain point even members of the makhzen in Morocco and the cabinet of Khedive Tawfiq in Egypt were foreign protégés. By the end of the century, large sections of new cosmopolitan cities such as Salonica, Smyrna, Beirut and Alexandria, which were the centers of economic activity, fell under consular control. In some cases, their municipalities were run by a foreign council. In these circumstances, many Christians who grew wealthy in trade with Europe were unwilling to risk their lives for the Ottoman Empire and paid an exemption tax for conscription (bedel askeri). Missionary schooling for Christians as well as Jews (through the Alliance Israélite universelle) which presented a European curriculum in European languages further undermined the effort to create equal citizenship by the state. The result was an increasing division among the population. While on the one hand the Muslim population increasingly attended public schooling, which after the end of the Tanzimat period became increasingly Islamically oriented, and were recruited into the army. On the other hand minorities attended missionary schools, became culturally and politically focused on Europe and were exempt from military service and taxes.

Despite these divisions, the introduction of citizenship was not a failure everywhere. Recent research has demonstrated that the impact of Arab nationalism and the support for Arab independence has been greatly exaggerated and that by and large the populations of what later became Lebanon, Syria, Iraq and Palestine - even minorities - remained loyal to the Ottoman empire until the First World War and even afterwards precisely for the reason that they felt they were citizens of the Empire. ${ }^{31}$ In her study of the responses in Palestine to the Young Turk Revolution, Michelle Campos demonstrates that cross-ideological, cross-ethnic and non-sectarian notions of a common citizenship were alive and kicking. Christians, Jews and Muslims welcomed the re-installment of the 1876 constitution and sent candidates to the parliament in Istanbul, participated in the boycott of foreign powers during the Balkan Wars of 1912-1913, and demonstrated a new common civil awareness and responsibility. ${ }^{32}$ The First World ended this solidarity, partly because of Turkification but mainly because the Ottoman empire was defeated and territories were divided among French, British and Italian colonial powers.

Citizenship rather than just nationalism and identity politics also explains the emergence of Turkey as a nation-state after the defeat of the Ottoman Empire. It was the regime Atatürk imposed in the 1920 s establishing complete

François-Marie Rosset: «Tyrkiske kvinner baker brød» (1790). 


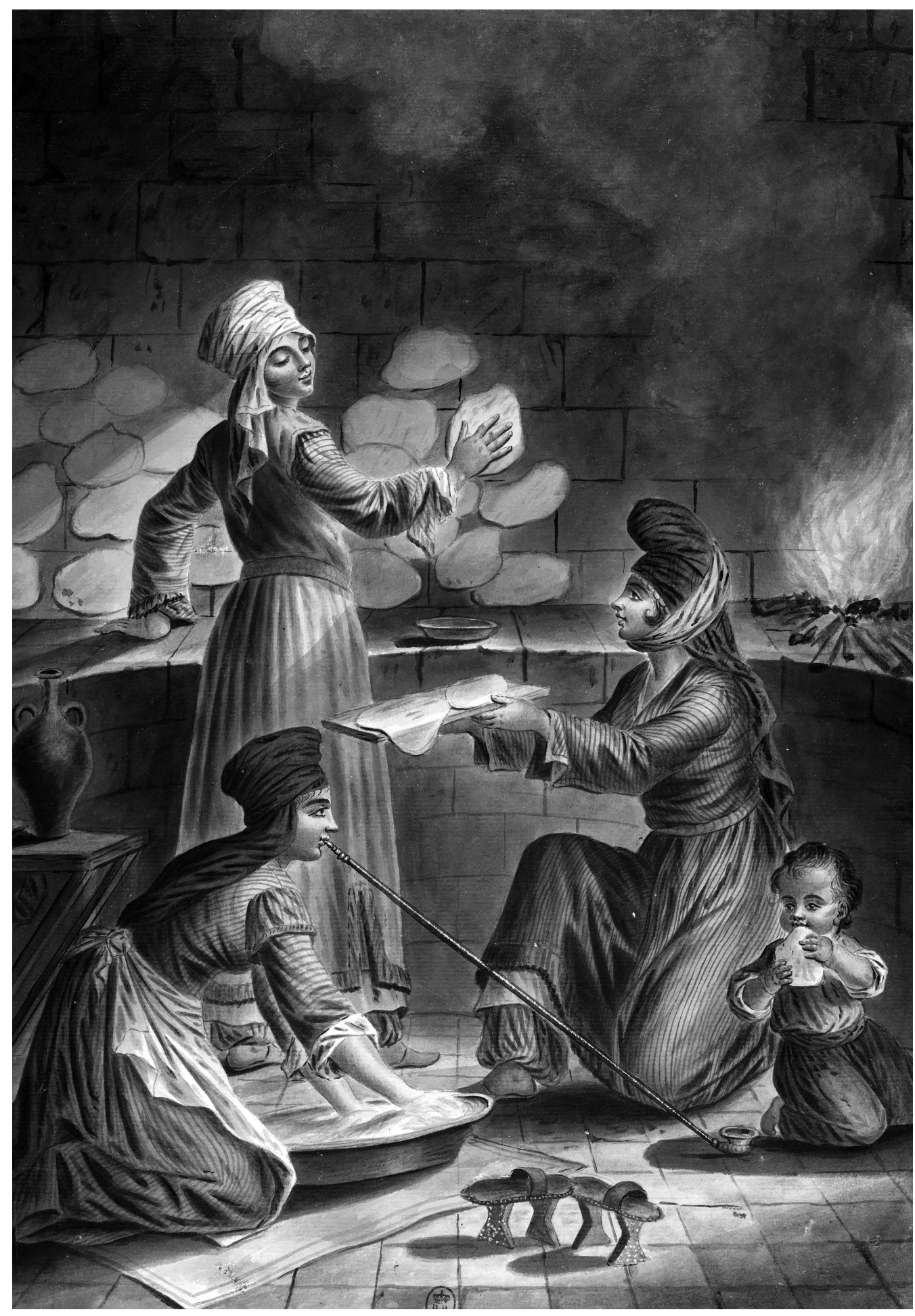


sovereignty, laying down rigorous boundaries, ending the Capitulations and foreign privilege, which produced a completely new citizenship regime based on the exclusion of non-Muslims, the integration the millions of refugees and the religious, cultural linguistic homogenization of the population that explains his success. ${ }^{33}$

\section{EGYPT BEFORE THE FIRST WORLD WAR}

Egypt's trajectory of citizenship was completely different from the Ottoman Empire, even if it formally was part of the empire until the proclamation of the British protectorate in 1914. Research on related topics of citizenship highlight four aspects that determined - often in contradictory ways - Egyptian citizenship regime in the nineteenth and early twentieth century: the bureaucratic unification of the country, the development of a public sphere, the rise of Egyptian proto-nationalism, and the economic incorporation into the modern world system.

Egypt in the nineteenth century was in many ways more successful in building national unity than the Ottoman Empire. With a much smaller population and territory, it was much easier for Mehmed Ali (1808-1848) to control the country and build a conscription army consisting of the Egyptian peasantry (fellahin). However, this army hardly contributed to nation-building during his lifetime as it was largely a dynastic army and not a nationalist army mobilized to defend the nation. ${ }^{34}$ More importantly, in the long run, was Mehmed Ali's success in building a centralized state which his successors expanded. Rapid urbanization, and the modernization of communication (roads, canals, telegraph, railroads) further enhanced the unification of the country. Since the 1870 s cultural development caught up and salons, clubs (masonic lodges), coffee houses, new theatres, and popular music helped to produce a sense of national unity and a common public sphere. Ziad Fahmy in his book on early notions of nationalism, demonstrates not only that new ideas on Egyptian identity and rights should be regarded as "proto-nationalism», but that the emergence of a «national public opinion» was not just limited to the elite but spread to the lower classes through the development of Egyptian colloquial newspapers and pamphlets and popular culture. ${ }^{35}$ The result was the beginning of what can be called modern citizenship. An alliance the Egyptian new middle class of effendis and village sheikhs and lower classes demanded economic, social and economic rights that transcended particular interests and promoted the common good. Fahmy demonstrates that justice had always been an essential element in Islam, but the idea that the people had rights laid down in a constitution, could hold rulers accountable, and represent themselves politically, was something

\section{Egypt in the 19th century was in many} ways more successful in building national unity than the Ottoman Empire.

completely new. To be sure, the modern terminology for citizen (muwatin) was rarely used, but intellectuals and the population used other terms that had a comparable meaning. Traditional terms such as «son/daughter of the land» (ibn/bint al-balad), the people (sha'b, ahali), commoners ('amma) acquired new meanings in a new context of changing state-citizen relations. They implied entitlements of individuals to civil rights (justice), the right to livelihood and economic claims (rightful income, reasonable level of taxes, spending money on the welfare of the common good instead of paying off the national debt to foreigners), and political rights (representation). ${ }^{36}$ The emergence of a modern 
notion of citizenship that developed in relationship the modern state is confirmed by John Chalcraft who recognizes that the petitions of the guild members reflect «a kind of kernel of citizenship». ${ }^{37}$ In return for the increased regulatory role and discipline (al-dabt wa-l-rabt) of the modern state and the imposition of higher taxes, ${ }^{38}$ guild members gained the right to elect their shaykhs and appeal against corruption and illegal collection of taxes to local courts. ${ }^{39}$ The «wish of people» (raghbat al-sha'b) as legitimating principle became commonly accepted. ${ }^{40}$

At the same time countervailing tendencies became preponderant. ${ }^{41}$ Chalcraft points out three reasons which led to the decline of even this trend toward citizenship. The first is the termination of the alliance between effendiyya and the lower classes of the guilds during the Urabi revolution; the second is the dismantlement of the guilds themselves and the establishment of unmitigated relations of former guild members and the state. The third reason was, however, decisive: the expansion of peripheral capitalism under British colonialism, which led to «labor squeezing» and the reduction of wages to subsistence level, or even lower. In the absence of any intermediary or organization to defend the rights to livelihood of guild members, its members resorted to «selfexploitation» in competition among each other. Ironically, Chalcraft argues, the fact that the working class did not pay taxes under the British, who had gradually abolished them, left them without political leverage. The British realized that unreasonably high taxes under khedive Ismail had led to political upheaval. By shifting the tax burden from direct taxes to the export sector (land tax and customs) they had been demobilized and could not make demands for social legislation, welfare, educational facilities and training. From other measures, such as education, it is clear that the British actively undermined the trend towards citizenship rights. ${ }^{42}$ The British citizenship regime was based on the colonial bargain between British authorities and the khedive and (after 1923 the king), large landowners, and those involved in the export economy of cotton. It was only when nationalism picked up after the Dinshway incident in 1905 (the unfair hanging of Egyptians peasants) and the nationalist movement regained interest in the working class and established training centers for it that a new coalition was built and strikes and other forms of protest were organized to defend economic rights, inaugurating a new phase in the development of citizenship.

\section{SYRIA BEFORE THE UNIFICATION WITH EGYPT}

Syria during the mandate period and before the unification with Egypt in 1958, provides another example in which citizenship approach can make a difference. Syrian history in this period is usually portrayed as an instable, artificial country, carved out of the Ottoman Empire by the Sykes-Picot Treaty. The heart of the continuous political crisis Syria was prone to is sought in the lack of a central identity. ${ }^{43}$ This is most pointedly expressed in the question whether it should merge with Iraq, join King Abdallah's Greater Syria project, or unite with Egypt. From a citizenship perspective, identity can only be part of the story and is important insofar it produces a stable or viable citizenship regime. Elisabeth Thompson makes clear why efforts to create common citizenship failed. An interesting attempt was to create equal citizenship by the mandate authorities through the emancipation of the peasants along the lines of what had happened in France. ${ }^{44}$ The purpose was to create a popular base for colonial rule and subvert the Sunni large landowners. These reforms were abandoned after the Great revolt of 1925 when the French had no choice but to work through the notable Sunni families. Lack of 
financial means led to indirect rule and undermined the nation-building process. ${ }^{45}$ Like in Egypt, the colonial bargain shored up a class system of unequal, differentiated citizenship basically excluding the rural population and granting special privileges to the notable class of large landowners and merchants ('ayān, dhawāt). For the same reason the French colonial authorities sought separate alliances with religious, especially Christian leaders, channeling considerable state funds for education through missionary schools. Public schools, the Tajhìz, did emerge to educate the sons of the middle classes, but only gradually. Common citizenship was further undermined by the promotion of ethnic and religious divisions by creating autonomous statelets of Alawites in the north-west, the Druze in the south and an autonomous region of Jazira in the north-east, as well as promoting religious communalism. ${ }^{46}$ Finally, the French prevented a democratic political system from emerging because independence would damage the economic interests of a small interest group who had investments in Syria, the parti colonial. Constantly interfering in the political process and blocking the nationalist movement such as the National Block from gaining support, the French mandate produced a highly instable political system of opportunistic politicians whose power was based on patronage and clientelism instead of mass mobilization of the broader population. Patrick Seale has masterfully analyzed the consequences of this policy; how during the period between the Second World War and the unification with Egypt in 1958, local, regional and international players collaborated in undermining the sovereignty of the state which Syrians had formally obtained after independence in 1946. Constantly shifting coalitions between Saudi Arabia, Egypt, and Iraq pitted corrupt politicians, who represented regional, religious, personal and class interests, against each other, splitting the society apart. ${ }^{47} \mathrm{He}$ points out that the Ba'ath - or for that matter the Ahāli group in Iraq, ${ }^{48}$ or the Society of National Renaissance in Egypt $^{49}$ - were more successful than the older «feudalist» politicians in bringing about a new citizenship regime based on land reforms, industrialization, workers' rights, and mass education. They failed, however, because they allied themselves with authoritarian military regimes, which in the end revived the regime of differential citizenship and partial bargains, with religious, economic, social interest groups.

\section{CONTRIBUTION}

In what way do these three examples illustrate the contribution citizenship approach can make to Middle Eastern studies and a reinterpretation of Middle Eastern history ${ }^{50}$

First, the formation of modern citizenship in the Middle East and North Africa is a continuous historical process that developed since the beginning of the emergence of the modern state and the evolution of completely different relations with its subjects since the beginning of the nineteenth century. This was an administrative and political development that occurred in response to the Western military and economic challenges to state sovereignty. The three examples show that citizenship and its vagaries are central to modernity in the Middle East. It is an essential factor in the concept of Ottomanism, it played a crucial role during the Urabi revolution of 18811882 and the emergence at the end of the nineteenth century of the public sphere and the rise of the proto-nationalist movement, which used a discourse of rights and changed the content of traditional terms to denote the commoners. In the interbellum it captures the specific character of the colonial bargain, and how the French in Mandate Syria failed to create a viable citizenship regime that would sustain a stable political system 
after independence. Rather than focusing on identity politics and pan-Arabism, research should acquire a sensitivity to look for new relations of citizenship developed by guilds, peasants, the working class and the new middle class (effendiyya) and efforts to develop concepts of a more viable, egalitarian citizenship regime to supplant the colonial bargain. Modern Middle Eastern history in this sense can be seen as a continuous attempt to come to grips with the changing state-citizen relations through devising new concepts as well as new practices of citizenship. This applies even to its latest manifestation, the Islamic State, where assertions of new forms of membership in Islamic political communities emerged under rebel governance. ${ }^{51}$ It is much more fruitful to regard the Islamic State as another attempt to create a viable citizenship regime of an

\section{The citizenship approach is a focal point} which integrates different developments that are otherwise seen as separate.

exclusive Sunni nation-state in response to sectarian, pro-Shi'i politics of Nouri al-Maliki (Vice President and Prime Minister between 2006-2014) than trying to explain its rise in Islamic terms as an authentic caliphate.

Second, the citizenship approach is a focal point which integrates different developments that are otherwise seen as separate. Citizenship, or rather differentiated citizenship, shows how relationship developed depending on local circumstances such as the existence of the Millet system, foreign interference, and the integration into the capitalist system. Citizenship is therefore a reflection of not just administrative regulation, standardization, and the increasing extractive capacity of the state, it is also influenced by integration of the region into the world economy, Islamic responses to that integration, and changes in identity formation. For instance, it is clear that the power of European countries demanded privileges and spread protégé status, and undermined sovereignty that is the precondition for citizenship. At the same time, the expansion / diffusion of peripheral capitalism and the «selfexploitation» of workers can be seen as (is) part of a process of economic inclusion but also of political exclusion. Citizenship also integrates different disciplines that have focused on very specific topics such Arab nationalism, the resilience of the authoritarian state, civil society, and social movement theory.

Third, in the words of Nyer, citizenship addresses the quintessential political. ${ }^{52}$ It analyzes how power affects citizens and how citizens can claim political space, contest the power of the state and create their own communities and defend their interests. Asking what the implications are for citizenship rights, notions and concepts of citizenship, immediately takes the political into account and analyzes the mechanisms of inclusion and exclusion, the forms of solidarity, and the level of active and passive citizenship.

Finally, the fear of imposing Western notions of citizenship is somewhat exaggerated. Citizenship studies is not the study of «cluster of absences or presences «, ${ }^{53}$ or «looking for the Holy Grail». Partly because citizenship is a 'natural' development of state-citizen relations in the modern era in which the state had become the central focus of claims, and because research has to be attuned what people themselves say. Research from Ussama Maqdisi to John Chalcraft has shown that the terms of ahali, sha'b have meant different things and have increasingly acquired meaning that is akin to citizenship and a rights discourse. This applies to the nineteenth 
century, but is also obvious in the ideology of the Ba'ath, and can also be discerned in the ideology of the Islamic movement.

It is quite possible to reconstruct premodern notions of citizenship, but they are very different from the modern one as the state was different.

Although the introduction of Nils A. Butenschøn does not cover the many aspects of citizenship in the Middle East, he has laid the groundwork for future study of citizenship in the region. Hopefully, it will not remain restricted to an «approach» but will develop into a discipline in itself by integrating many of the works already done and incorporating and reanalyzing the existing literature, as well as promote new research. In sum, citizenship might seem illusive and spread between «here» and «there» but in fact looking more carefully, it is «everywhere».

\section{- $f \cdot$}

ROEL MEIJER is Associate professor in Islam studies at Radboud University, The Netherlands.

1 Will Hanley, Identifying with Nationality: Europeans, Ottomans and Egyptians in Alexandria (New York: Columbia University Press, 2017), 19.

2 Hanley, Identifying with Nationality: Europeans, Ottomans and Egyptians in Alexandria, 55.

3 Bryan S. Turner, «Islam, Civil Society, and Citizenship: Reflections on the Sociology of Citizenship and Islamic Studies", in Citizenship and the State in the Middle East: Approaches and Applications, eds. Nils Butenschøn, Uri Davis and Manuel Sarkis Hassassian (New York: Syracuse University Press, 2000), 28-48.

4 Sami Zubaida, Law and Power in the Islamic World (London: IB Tauris, 2003).

5 Engin Isin, «Citizenship after Orientalism: Ottoman Citizenship", in Citizenship in a Global World: Routledge Studies and Governance and Change in the Global Era, eds. Fuat Keyman and Ahmet Icduycu (London, New York: Routledge, 2005), $31-51$.

6 Wael B. Hallaq, The Impossible State: Islam, Politics, and Modernity's Moral Predicament (New York: Columbia University Press, 2013).

7 Timothy Mitchell, Colonizing Egypt (The American University in Cairo Press, 1988).
8 Gianluca P. Parolin, Citizenship in the Arab World: Kin, Religion and Nation-State (Amsterdam: Amsterdam University Press, 2009).

9 Lauren Banko, The Invention of Palestinian Citizenship, 19181947 (Edinburgh University Press, 2016).

10 Michelle U. Campos, Ottoman Brothers: Muslims, Christians, and Jews in Early Twentieth-Century Palestine (Stanford: Stanford University Press, 2011).

11 Elizabeth Thompson, Colonial Citizens: Republican Right, Paternal Privilege, and Gender in French Syria and Lebanon (New York: Columbia University Press, 2000).

12 Rania Maktabi, «The Politicization of the Demos in the Middle East: Citizenship between Membership and Participation in the State» (PhD dissertation, University of Oslo, 2012)

13 Ussama Makdisi, The Culture of Sectarianism: Community, History, and Violence in Nineteenth-Century Ottoman Lebanon (Berkeley: University of California Press, 2000).

14 Donald Quataert, The Ottoman Empire, 1700-1922 (Cambridge: Cambridge University Press, 2005).

15 Bruce Masters, Christians and Jews in the Ottoman Arab World: The Roots of Sectarianism (Cambridge: Cambridge University Press, 2001); Heather J. Sharkey, A History of Muslims, Christians and Jews in the Middle East (Cambridge: Cambridge University Press, 2017).

16 John Chalcraft, The Striking Cabbies of Cairo and Other Stories: Crafts and Guilds in Egypt, 1863-1914 (New York: SUNIY, 2005).

17 Joel Beinin and Zachary Lockman, Workers on the Nile: Nationalism, Communism, Islam, and the Egyptian Working Class, 1882-1954 (Princeton: Princeton University Press, 1988).

18 Nils A. Butenschøn, Uri Davis and Manuel Hassassian (eds), Citizenship and the State in the Middle East: Approaches and Applications (New York: Syracuse University Press, 2000).

19 Suad Joseph (ed.), Gender and Citizenship in the Middle East. With a foreword of Deniz Kandiyoti (New York: Syracuse University Press, 2000).

20 Nils A. Butenschøn, «Introduction», in Nils A. Butenschøn, Uri Davis and Manuel Hassassian (eds), Citizenship and the State in the Middle East: Approaches and Applications, 11.

21 Butenschøn, «Introduction», 7.

22 Roel Meijer and Nils A. Butenschøn (eds), The Crisis of Citizenship in the Arab World (Leiden: Brill, 2017).

23 Lisa Wedeen, Ambiguities of Domination: Politics, Rhetoric, and Symbols in Contemporary Syria (Chicago: University of Chicago Press, 1999), 51.

24 Samir Khlail (Kanan Makiya), Republic of Fear: The Inside Story of Saddam's Iraq (New York: Panteon Books, 1989), 43. 
25 Roel Meijer and Nils A. Butenschøn (eds), The Crisis of Citizenship in the Arab World (Leiden: Brill, 2017); Nils Butenschon and Roel Meijer (eds.) The Transition of the Middle East: The Centrality of Citizenship in the Middle East (Cheltenham: Edward Elgar, 2018).

26 Sharkey, A History of Muslims, Christians and Jews in the Middle East.

27 Baki Tezcan, «Ethnicity, Race, Religion and Social Class», in The Ottoman World, ed. Christine Wood (London, New York: Routledge, 2012), 159-170.

28 Erik Jan Zürcher, «The Ottoman Conscription System», The Young Turk Legacy and Nation Building: From Ottoman Empire to Atatürk's Turkey (London: IB Tauris, 2010), 154166.

29 Donald Quataert, The Ottoman Empire, 1700-1922 (Create Space Independent Publishing Platform, 4rth Edition, 2017), 65-68.

30 Donald Quataert, "Clothing Laws, State and Society in the Ottoman Empire, 1720-1829», International Journal of Middle East Studies, 29, no. 3 (1997): 403-425.

31 Hasan Kayali, Arabs and Young Turks: Ottomanism, Arabism, and Islamism in the Ottoman Empire, 1908-1918 (Berkeley: University of California, 1997).

32 Campos, Ottoman Brothers.

33 For more on this development, see Basak Ince, Citizenship and Identity in Turkey: From Ataturk's Republic to the Present Day (London: I.B. Tauris, 2012).

34 Khalid Fahmy, All the Pasha's Men: Mehmed Ali, His Army and the Making of Modern Egypt (The American University in Cairo Press, 2002), 282-284.

35 Ziad Fahmy, Ordinary Egyptians: Creating the Modern Nation through Popular Culture (Stanford: Stanford University Press, 2011), 60 .

36 Fahmy, Ordinary Egyptians, 46, 74-87, 126

37 Chalcraft, The Striking Cabbies, 74.

38 Chalcraft, The Striking Cabbies, 69-70.

39 Chalcraft, The Striking Cabbies, 77-80.

40 Chalcraft, The Striking Cabbies, 93-94.

41 Chalcraft, The Striking Cabbies, 67.

42 Chalcraft, The Striking Cabbies, 148

43 Philip Khoury, Syria and the French Mandate: The Politics of Arab Nationalism, 1920-1945 (Princeton: Princeton University Press, 1987).

44 Thompson, Colonial Citizens, 45.

45 Thompson, Colonial Citizens, 73-90.
46 Benjamin Thomas White, The Emergence of Minorities in the Middle East: The Politics of Community in French Mandate Syria (Edinburgh: Edinburgh University Press, 2012).

47 Patrick Seale, The Struggle for Syria (London: IB Tauris, 1965).

48 Charles Tripp, A History of Iraq (Cambridge: Cambridge University Press), 85-86, 88-89.

49 Roel Meijer, The Quest for Modernity: Secular Liberal and LeftWing Political Thought in Egypt, 1945-1958 (London: Routledge /Curzon, 2002), 37-65.

50 For a full discussion of the contribution see, Roel Meijer and Nils Butenschøn, «Introduction», in The Crisis of Citizenship in the Arab World, eds. Roel Meijer and Nils Butenschøn (Leiden: Brill, 2017), 1-37.

51 Brynjar Lia, «The Jihādī Movement and Rebel Governance: A Reassertion of a Patriarchal Order?», Die Welt des Islams 57, no. 3-4 (2017).

52 Peter Nyers, «Introduction: Why Citizenship Studies», Citizenship Studies 11, no. 1 (2007): 1-4.

53 Isin, «Citizenship after Orientalism», 2. 